\title{
The Status of the Development of Wind Energy in Nigeria
}

\author{
Wasiu Olalekan Idris ${ }^{1,2}$, Mohd Zamri Ibrahim $1,2, *$ (i) and Aliashim Albani 1,2 (1) \\ 1 Renewable Energy \& Power Research Interest Group (REPRIG), Eastern Corridor Renewable Energy (ECRE), \\ Universiti Malaysia Terengganu, Kuala Terengganu, Terengganu 21030, Malaysia; \\ p4382@pps.umt.edu.my (W.O.I.); a.albani@umt.edu.my (A.A.) \\ 2 Faculty of Ocean Engineering Technology and Informatics, Universiti Malaysia Terengganu, \\ Kuala Terengganu, Terengganu 21030, Malaysia \\ * Correspondence: zam@umt.edu.my
}

Received: 21 October 2020; Accepted: 17 November 2020; Published: 26 November 2020

\begin{abstract}
The advancement of wind energy farms in the developed part of the world has dramatically reduced the cost of wind energy turbine systems down to a competitive price and has contributed to a reduction in global warming, which affects the worldwide population. The renewed interest in a sustainable, avoidable, and reliable energy system has contributed to the actions of the federal government of Nigeria regarding renewable energy systems. Many projects have been completed using solar energy in rural communities as well as with government higher institutions of learning, while little attention has been on wind energy, except for the $10 \mathrm{MW}$ land base in a village in the Kastina State. In this study, the stages of development were itemized in regard to the assessment, economic analysis, and hybrid system of wind energy in Nigeria. The available reported wind speed were studied at 10, 20, 40, 60, 80, 100, and $120 \mathrm{~m}$. Recommendations were highlighted to enhance wind energy research, development, and its application.
\end{abstract}

Keywords: renewable energy system; hybrid system; wind energy resources; wind energy potential; Weibull distribution functions

\section{Introduction}

The campaign for renewable energy in the world has taken the center stage due to global warming and the need to avoid fossil fuel [1]. Every nation must wake up to stand up for their energy demand by boosting the existing supply of renewable energy. Moreover, nature blessed us with various energy sources ranging from biomass, wind, wave, solar, hydropower, geothermal, etc., and if utilized, could cater for the shortfall in energy supply [2]. For a nation to develop, there must be energy resources that will enhance its economic power and allow competitiveness among the nations of the world [3]. The advancement that has taken place in wind energy farm expansion and its deployment spread across the world continues to increase the renewable energy market with aggregate installed power up to $591 \mathrm{GW}$, as of 2018 [4]. The wind application for onshore and offshore use has played a significant role in meeting up with the rise in energy demand in developed nations of the world, which has brought about emerging investment in wind energy generation due to its low cost [5]. The foremost offshore wind energy was launched in the early 90s in Denmark [6]. There is a greater prospect in the wind energy market in Asia and Europe. Europe has improved its net wind power by nearly $2650 \mathrm{MW}$ in the offshore environment as of 2018, resulting in an aggregate capacity of 18,499 MW [7]. However, Nigeria is battling with an insufficient power supply to accelerate its economic value and reduce the emission factors that have contributed to global warming. The overdependence on hydropower systems, which vary with seasons and rely on water levels can result in lower power supply. The advancement of 
energy is a huge task in Nigeria due to many challenges. The continuous power failures aggravated the nation's poverty level, causing disruption of various industries that depend solely on other means of energy usages such as petrol and diesel engines. The resulting effects are emission discharges, which lead to a higher cost of production and global warming. Nigeria's electricity consumption per capital base on grid system is $126 \mathrm{kWh}$, which is comparatively low to other prominent Africa countries, as only $49 \%$ have access to electricity [8,9]. The economy could be rejuvenated when alternative means of energy is provided and will also cater for the rise in population [10]. The rise in energy demand, inadequate supply of electricity, and the need for power supply has caused a renewed interest in alternative energy sources [11]. Nigeria is blessed with many natural energy sources that could be explored, such as the gas turbine system, when insecurity in the Niger-Delta and bunkering operation are adequately resolved [12]. The capacity generated as of 2007 was aggregated as $7876 \mathrm{MW}$, with thermal energy amounting for $75.9 \%$ and the hydropower system for $24.1 \%$. The operational capacity back then was 3149 MW. This capacity is not an adequate base for the existing population [13]. Presently, Nigeria's electrification growth is steadily improving, currently at $93 \%$, in regard to the 20 year horizon compared to Bangladesh and Indonesia, with percentages of $451 \%$ and $372 \%$, using a similar horizon [14]. The sustainable energy systems must be provided, based on the available renewable energy policy. Accelerating the national electricity supply access rate is a step towards succeeding at the proposed SDGs (Sustainable Development Goals) [15]. The Nigerian government have seen the need to establish an off-grid energy system for rural communities by empowering the REA (Rural Electrification Agency) for this responsibility. This agency is funded by the Nigerian government and the World Bank under the NEP (National Electrification Project) [16]. Additionally, Nigeria's renewable energy policy is itemized as follows: providing the fund for research and development of renewable energy; creating an industry that will invest in renewable energy materials and products, and the establishment of renewable energy standards [3].

It was suggested that the $[17,18]$ northern part possesses larger wind resources in comparison to the southern region of the country. This review comprehensively details various studies on wind energy system as a sustainable, reliable, and accessible energy mix in Nigeria, the West African sub-region of Africa. This review is sub-divided into the assessment of wind energy resources, economic analysis of wind energy resources, hybrid analysis of wind energy resources, research recommendation, and suggestion for future studies and conclusion. There were over 300 works of literature found in Scopus (ScienceDirect), Google Scholar, and the web of science. The studies were sorted out to obtain the relevant ones and in-depth work was done on it. Summarily, 100 journals were selected and categorized based on the sections listed above, which resulted in $52 \%$ on assessment, $15 \%$ on economic analysis, and $27 \%$ on hybrid system.

\section{Assessment of Wind Energy Resources}

A proper illustration of available wind resources provides room for adequate planning and the project could be executed by the developer, government agency, as well as investors. The wind speed reflects which categories of wind turbine systems could be applied for each location, ranging from a small, medium, and large turbine base of existing technologies. Analysis of wind energy resources in various locations in Nigeria was investigated from year 1951 to 1975 at $10 \mathrm{~m}$ height. The northern part produced the highest wind, especially Nguru and Sokoto, while the southern region produced less wind, from 1.40 to $3 \mathrm{~m} / \mathrm{s}$. The maximum value of wind speed occurred in April to August for all the sites [19]. Adekoya et al. analyzed wind potential in 30 locations in Nigeria using up to 22 years of wind speed data. The mean wind speed obtained ranged from 1.5 to $4.1 \mathrm{~m} / \mathrm{s}$, with a power density of 5.7 to $22.5 \mathrm{~W} / \mathrm{m}^{2}$. It was depicted that the northern part possesses higher mean wind speed compared to the southern part of the country [20]. Anyanwu carried out analysis on the Owerri wind energy profile, which had an available annual mean power density of $7.66 \mathrm{~W} / \mathrm{m}^{2}$ with an annual mean of $60.29 \mathrm{kWh} \cdot \mathrm{m}^{2}$ [21]. Ngala [22] utilized the Weibull distribution to assess wind energy in the Borno State, and it was affirmed that power densities at $25 \mathrm{~m}$ height were estimated to fall between 4.712 and 
27.449 MWh/month. This study placed emphasis on wind energy resources in Ibadan Oyo State by adopting the Weibull distribution function for the years 1995 to 2004, and the resulting power density obtained was $15.484 \mathrm{~W} / \mathrm{m}^{2}$ with an annual mean wind speed of $2.75 \mathrm{~m} / \mathrm{s}^{2}$ which could be used for lower power equipment [23]. The assessment of wind power for Enugu was done using the Weibull distribution, the result showing that a hub height of $10 \mathrm{~m}$ contains a mean wind speed, scale factor, shape parameter, and skew of $2.5 \pm 0.3 \mathrm{~m} / \mathrm{s}, 4.31 \mathrm{~m} / \mathrm{s}, 2.21$ and -0.46 , respectively [24]. Moreover, Ajayi observed a research gap on the assessment of the wind energy profile in south-west, and conducted a study that depicted that a large scale production of power could be emanated in Lagos and Oyo State with a mean wind speed of 2.9 to $5.8 \mathrm{~m} / \mathrm{s}$, whereas others could employ a small scale production [25]. Assessment was done to analyze wind speed in the southern section of Nigeria using the two-parameter Weibull probability density function for the period of 1971 to 2007 . Annual mean wind speeds ranging from 3.09 to $4.15 \mathrm{~m} / \mathrm{s}$ were depicted [26]. Ayodele investigated the use of a geographical information system-base for wind farm site selection using the fuzzy analytical model. The approximate value of the area appropriate for the wind energy device is $125,728.6 \mathrm{~km}^{2}$ and revealed that the northern part is most suitable for wind exploration. Moreover, the assessment of wind energy potential in Jos using the Weibull parameters was analyzed, as quoted in [12,27]. Fagbenle [28] utilized the Weibull parameters to assess wind energy resources in Maiduguri and Potiskum at $10 \mathrm{~m}$ height. The influence of altitude pertaining to air density that impacts the wind turbine is explored. An optimized sizing of a new WECs for mobile application was proposed to ease the effects, and $1 \%$ of wind turbine output was lost when placed at $100 \mathrm{~m}$ [29]. Estimation of wind energy potential was illustrated for the north-east region using the Weibull distribution function, which spans 37 years, with wind speed data at $10 \mathrm{~m}$ height. It was observed that Maiduguri and Bauchi depicted the best results, at peak values of $6.10 \mathrm{~m} / \mathrm{s}$ and $7.04 \mathrm{~m} / \mathrm{s}$ and their respectful mean power densities were $173.70 \mathrm{~W} / \mathrm{m}^{2}$ and $299.88 \mathrm{~W} / \mathrm{m}^{2}$, while Potiskum had an annual mean wind speed of $4.80 \mathrm{~m} / \mathrm{s}$ and power density of $103.14 \mathrm{~W} / \mathrm{m}^{2}$ [30]. Analysis of wind energy resources was considered in the north-central region with Minna identified as the best site, while the least wind energy occurred in Bida at $10 \mathrm{~m}$ height [31]. The south-west region was evaluated using the Weibull distribution on 37 years of wind data, the least annual mean power was achieved using DeWind 48 as $4.21 \mathrm{~kW} / \mathrm{a}$ in Abeokuta, whereas the highest results occurred by employing DeWind D7-1.5 MW to $430.10 \mathrm{~kW} / \mathrm{a}$ in Lagos [32]. The potential of wind energy resources was simulated in Omu Aran Kwara State from 2014 to 2018, the highest average wind speed obtained at $10 \mathrm{~m}$ height was $7.925 \mathrm{~m} / \mathrm{s}$ with minimum value of $3.675 \mathrm{~m} / \mathrm{s}$ [33]. The fluctuation in wind speed data was evaluated by employing recurrence quantification analysis as well as a recurrence plot, which studied the non-linear deterministic varying process. It was concluded that the rainy season is more chaotic compared to the dry season, and that the northern part of Nigeria depicts higher predictability of wind in respect to others region [34]. The potential of future wind energy resources due to the effect of afforestation and global warming was investigated in Nigeria. It was deduced that global warming gives rise to wind speed while afforestation has a significant negative effect on future wind speed throughout the country [35]. This article is mainly for the proper scrutiny of wind data set, based on the social, environmental and financial implication, which can be used by various stakeholders for the investment and development of a scale wind energy device in Nigeria [36]. The wind energy resources were visualized in six areas of south-south Nigeria for a hybrid system by applying the Weibull distribution function with values of wind speed estimated to be from 3.21 to $4.19 \mathrm{~m} / \mathrm{s}$ at $10 \mathrm{~m}$ height [14]. Okeniyi explored the Weibull as well as the Rayleigh distribution to verify the wind speed resources in Akure for an 11 year data period. The mean power density recorded was $22.26 \mathrm{~W} / \mathrm{m}^{2}$ and $18.51 \mathrm{~W} / \mathrm{m}^{2}$ for both Rayleigh and Weibull, accordingly, while their corresponding mean wind speed was $2.70 \mathrm{~m} / \mathrm{s}$ and $2.71 \mathrm{~m} / \mathrm{s}$ [37]. When an hybrid system of wind and solar energy was examined, the yearly energy production was 283,027 per $\mathrm{kWh}$, but when connected with diesel it was more cost effective compared to standalone wind/solar hybridization [38]. Analysis of wind energy resources for the south-south region of Nigeria was explored for the water pumping system, the mean power density and annual energy varied in different locations as $6.28 \leq \mathrm{APD} \leq 102.90 \mathrm{~W} / \mathrm{m}^{2}$ and $422 \leq \mathrm{AE} \leq 747 \mathrm{kWh} / \mathrm{m}^{2}$ per 
year, respectively [39]. In order to simulate a hybrid system, the wind energy resources were examined in the six regional parts of Nigeria using the Weibull distribution function, and the wind speed was found to be in the range 3.74-11.04 m/s [40]. Artificial neural networks were utilized to forecast wind speed as output of the system with other parameters that could influence wind speed as an input variable using 20 years of data set. The resulting wind speed was found to be 0.9 to $13.1 \mathrm{~m} / \mathrm{s}$, having a mean absolute percentage error of $8.9 \%$ in form of a map that could be employed to assess wind energy resources in any part of Nigeria [41]. Assessment of the wind energy potential in the north-central part of Nigeria was estimated based on the Weibull distribution functions for a period of 36 years. Their power density fell in the range $16.57-76.40 \mathrm{~W} / \mathrm{m}^{2}$, while annual average wind speed was 2.75 to $4.57 \mathrm{~m} / \mathrm{s}$, and they are therefore suitable for an off-grid system [42]. In the Niger-Delta part of Nigeria, the wind resources for seven sites were analyzed using the Weibull distribution functions with an annual energy output of 4.07 to $145.6 \mathrm{MWH}$. It was asserted that a $35 \mathrm{~kW}$ wind energy turbine was recommended for all site locations owing to the larger capacity factor of this value [43]. Similarly, wind energy resources were investigated in Umudike, using 10 years of wind speed data set, by employing the Weibull distribution functions. The annual wind power estimated was $3101 \mathrm{KWh} / \mathrm{m}^{2}$ in this location [17]. Since Nigeria possesses a low wind speed profile, appropriate material selection for horizontal axis wind turbine is a step in the right direction. Four different materials were investigated by exploring a multi-criterial decision method which includes glass fiber, mild steel, aluminum alloy, and stainless steel. Aluminum performed best compared to the other three [44]. The cross regional analysis was done for wind energy resources at $10 \mathrm{~m}$ height by employing the Weibull distribution functions, Kano and Jos produced the most excellent wind energy potentials that could be connected to grid systems that were cost effective, out of the 15 sites considered [45]. The accessibility of wind energy for water pumping system was quantified for three locations; Iseyin, Saki, and Ibadan [46]. Amoo studied the wind energy profile in Abeokuta and Ijebu-ode by utilizing the Weibull distribution function using a data set from 1990 to 2010 at $10 \mathrm{~m}$ height. The yearly mean wind speed for the two sites fell between 2 and $5 \mathrm{~m} / \mathrm{s}$, while their power density was 4.26 to $76.46 \mathrm{~W} / \mathrm{m}^{2}$ [47]. The resource analysis of wind energy was quantified based on a energy conversion system within a period of 25 to 37 years at $10 \mathrm{~m}$ height in the six regional parts of Nigeria. Annual mean energy produced was 2.24 to 12,521.55 MWh [48]. The study explored the effect of climate change on wind energy utilization and concluded that the changes were significant, which one needs to be mindful of when considering wind energy installation [49]. Four selected sites, namely: Katsina, Jos, Enugu, and Kaduna were investigated for wind energy resources using the Weibull parameters and exergy analysis [50]. Three sites were analyzed in the Oyo State using the Raleigh distribution model. The average wind speed was found to be 2.85 to $5.20 \mathrm{~m} / \mathrm{s}$, while their corresponding power densities fell within the range 27.08-164.48 W/m $/ \mathrm{m}^{2}$ [51]. The typical meteorological year was formulated based on 34 years of data sets for weather data, which included wind speed [52]. Oyekola analyzed the performance of horizontal wind axis turbine in relation to parameters that influence the efficiency of the system [53]. Possibilities of employing renewable energy for pumping system was demonstrated for the central part of Nigeria, which depicted the sustainability and cost effectiveness of the system [54]. The wind thermosphere was studied for Abuja [55]. Assessment of wind energy potential was explored in Danjawa village, Sokoto, within the period from 1991 to 2010 by adopting the Weibull distribution function at $18 \mathrm{~m}$ hub height. The average wind speed was 4.40 to $7.89 \mathrm{~m} / \mathrm{s}$ and mean power density resulted from 7.65 to $92.90 \mathrm{~W} / \mathrm{m}^{2}$ [56]. The Weibull distribution function was employed for wind resources in major cities in the south-south region. The average wind speed depicted was 2.1 to $3.0 \mathrm{~m} / \mathrm{s}$ while wind power density ranged from 6.0 to $16.3 \mathrm{~W} / \mathrm{m}^{2}$ [57]. This present study analyzed wind energy resources in five states of the south-west region by utilizing the Weibull distribution function for a period of 51 years. The mean monthly wind speeds fall between 2.7 to $7.7 \mathrm{~m} / \mathrm{s}$, having seasonal variation for rainy season as 3.8 to $6.9 \mathrm{~m} / \mathrm{s}$ while the dry season was 3.5 to $6.6 \mathrm{~m} / \mathrm{s}$. The average power density per year for Ikeja, Osogbo, Abeokuta, Akure, and Ibadan is 387.07, 87.34, 65.09, 145.07, and $176.96 \mathrm{~W} / \mathrm{m}^{2}$ [58]. Analysis of wind resources in Warri, Calabar, and Kastina were simulated by the Weibull distribution function 
and Gumble. Their average wind speed in the wet season are 7.62, 7.64, and $7.61 \mathrm{~m} / \mathrm{s}$, while their wind power densities are $257.75,259.55$, and $257.11 \mathrm{~W} / \mathrm{m}^{2}$, respectively. The dry seasonal average wind speeds are $9.17,9.20$, and $9.17 \mathrm{~m} / \mathrm{s}$ and their corresponding power densities are 449.73, 454.10, and $449.12 \mathrm{~W} / \mathrm{m}^{2}$ [59]. The Weibull distribution model has been employed in analyzing a 10-year wind data from six chosen locations in Nigeria, three each from northern and southern settlements. The resource analysis for wind energy was done for Bauchi, Sokoto, Abeokuta, Lokoja, Port Harcourt, and Owerri, employing the Weibull distribution function. Their average wind speed per year are as follows; 4.37, 4.33, 2.76, 4.52, 3.27, and $3.25 \mathrm{~m} / \mathrm{s}$, respectively, while their corresponding power densities are $59.56,49.14,14.22,69.94,23.76$, and $25.77 \mathrm{~W} / \mathrm{m}^{2}$ [60]. Ogolo studied wind energy resources using the Weibull distribution function based on 12-hourly wind speed data [61]. The wind energy resource was visualized in Makurdi by utilizing the Weibull distribution functions at $10 \mathrm{~m}$ height. The wind speed obtained is more than the $4 \mathrm{~m} / \mathrm{s}$ threshold for turbine operation and its annual average power density was $86.85 \mathrm{~W} / \mathrm{m}^{2}$ [62]. Analysis of wind energy potential in Kano was illustrated based on the Weibull distribution function, using 21 years monthly average wind speeds, which fall on 6.6 to $9.5 \mathrm{~m} / \mathrm{s}$, and the monthly power density, which was 3.6 to $12.5 \mathrm{MWh} / \mathrm{m}^{2}$ [63]. Moreover, the wind characteristic was investigated in the south-east geopolitical zone at $10 \mathrm{~m}$ hub height. Annual average wind speed for Onisha, Enugu, and Owerri were 3.59, 5.42, and $3.36 \mathrm{~m} / \mathrm{s}$ while their respected power density were 28.34, 96.98, and $23.3 \mathrm{~W} / \mathrm{m}^{2}$ [64]. The wind energy potential was analyzed for Porth Harcourt in the River State using the Raleigh distribution function. The mean wind velocity obtained was $17.75 \mathrm{~m} / \mathrm{s}$, having a power density function of $1370 \mathrm{~W} / \mathrm{m}^{2}$ at a hub height of $50 \mathrm{~m}$, in River State [65]. Akinsola studied wind speed resources utilization at the Koluama, Bayelsa State, Nigeria, which was subjected to the Weibull distribution function analysis. The average wind speed recorded during the dry season was $4.05 \mathrm{~m} / \mathrm{s}$, while the rainy season was estimated to be $4.32 \mathrm{~m} / \mathrm{s}$. The wind power density fell within 82 to $145 \mathrm{~W} / \mathrm{m}^{2}$, which is a suitable area for a small scale turbine system [66]. Suitable techniques for the Weibull parameter estimation was investigated, and the momentum model was found to be more appropriate compared to the energy pattern as well as to graphical methods [67]. The average wind speed for the coast region of the south-south was measured as 2.1 to $3.0 \mathrm{~m} / \mathrm{s}$ and the value of power density was 6.0 to $16.3 \mathrm{~W} / \mathrm{m}^{2}$ using the Weibull distribution function [68]. Most of the studies itemized above utilized the Weibull distribution function while few studies employed the Raleigh distribution and fuzzy analytical model based on Geographical Information System (GIS). Additionally, analysis was done regarding national, geo-political zones, states, cities, and rural areas that could not have access to the national grid. It could be worth mentioning that most studies concentrated more on the northern part of the country, whereas there is a need to study other parts. Then, the data base should be established as the national data for wind energy and updated periodically to account for climate mitigation and other factors that could have impacted the wind speed. Generally, an extrapolation was applied to their studies at various heights using the power law. The other factors that need to be considered to ascertain the extrapolated values were left out, such as topographic characteristics, turbine instalment, and settlements. The lack of validation on data sets by comparing national meteorological data with other available sources such as HYCOM, Metar data from airports, and so on, had impacts on the reliability of the assessment done. The aforementioned data bank could be explored for validation processes to meet with the standards set for wind energy utilization in the world. The summary of the data obtained was depicted in Table 1. 
Table 1. The data summary of assessment of wind energy resources.

\begin{tabular}{|c|c|c|}
\hline Site & Reported Data & Ref. \\
\hline Nigeria & $\begin{array}{l}\text { The northern part consists of the highest wind, especially Nguru and } \\
\text { Sokoto, while the southern region produced less wind, } 1.40 \text { to } 3.00 \mathrm{~m} / \mathrm{s} \text {. } \\
\text { The maximum value of wind speed occurred in April to August for all } \\
\text { the sites. The mean wind speed obtained ranged from } 1.5 \mathrm{~m} / \mathrm{s} \text { to } 4.1 \mathrm{~m} / \mathrm{s} \text {, } \\
\text { with a power density of } 5.7 \text { to } 22.5 \mathrm{~W} / \mathrm{m}^{2} \text {. Annual mean energy } \\
\text { produced was } 2.24 \text { to } 12,521.55 \mathrm{MWh} \text {. }\end{array}$ & {$[19,20,48]$} \\
\hline Owerri & $\begin{array}{l}\text { The annual mean power density available was } 7.66 \mathrm{~W} / \mathrm{m}^{2} \text { with an } \\
\text { annual mean of } 60.29 \mathrm{kWh} \mathrm{m}^{2} .\end{array}$ & [21] \\
\hline Oyo State & $\begin{array}{l}\text { The power densities at } 25 \mathrm{~m} \text { height were estimated to fall between } 4712 \\
\text { and } 27,449 \mathrm{MWh} / \mathrm{month} \text {, and the power density obtained was } \\
15,484 \mathrm{~W} / \mathrm{m}^{2} \text { with an annual mean wind speed of } 2.75 \mathrm{~m} \text {. The average } \\
\text { wind speed was found to be } 2.85 \text { to } 5.20 \mathrm{~m} / \mathrm{s} \text {, while their corresponding } \\
\text { power densities fall within the range } 27.08-164.48 \mathrm{~W} / \mathrm{m}^{2} \text {. }\end{array}$ & {$[22,51]$} \\
\hline Enugu & $\begin{array}{l}\text { The assessment at a hub height of } 10 \mathrm{~m} \text { contains mean wind speed, scale } \\
\text { factor, shape parameter, and skew of } 2.5 \pm 0.3 \mathrm{~m} / \mathrm{s}, 4.31 \mathrm{~m} / \mathrm{s}, \\
2.21 \text { and }-0.46 \text { accordingly. }\end{array}$ & [23] \\
\hline South-west & $\begin{array}{l}\text { The mean wind speed of } 2.9 \text { to } 5.8 \mathrm{~m} / \mathrm{s} \text { whereas others could employ a } \\
\text { small-scale production. The least annual mean power is achieved using } \\
\text { DeWind } 48 \text { as } 4.21 \mathrm{~kW} / \mathrm{a} \text { in Abeokuta, whereas the highest occur by } \\
\text { employing DeWind D7-1.5 MW to } 430.10 \mathrm{~kW} / \mathrm{a} \text { in Lagos. The mean } \\
\text { monthly wind speeds fall on } 2.7 \text { to } 7.7 \mathrm{~m} / \mathrm{s} \text {, having a seasonal variation } \\
\text { for the rainy season as } 3.8 \text { to } 6.9 \mathrm{~m} / \mathrm{s} \text {, while the dry season was } 3.5 \text { to } \\
6.6 \mathrm{~m} / \mathrm{s} \text {. The average power density per year for Ikeja, Osogbo, } \\
\text { Abeokuta, Akure, and Ibadan are } 387.07,87.34,65.09,145.07 \text {, } \\
\text { and } 176.96 \mathrm{~W} / \mathrm{m}^{2} \text {, respectively. }\end{array}$ & {$[25,31,58]$} \\
\hline Southern region & The annual mean wind speeds ranged from 3.09 to $4.15 \mathrm{~m} / \mathrm{s}$. & [26] \\
\hline Nigeria & GIS fuzzy analytical model. & [28] \\
\hline North-east & $\begin{array}{l}\text { It was observed that Maiduguri and Bauchi depicted the best results at } \\
\text { peak values of } 6.10 \mathrm{~m} / \mathrm{s} \text { and } 7.04 \mathrm{~m} / \mathrm{s} \text {, and their respectful mean power } \\
\text { densities were } 173.70 \mathrm{~W} / \mathrm{m}^{2} \text { and } 299.88 \mathrm{~W} / \mathrm{m}^{2} \text {, while Potiskum had an } \\
\text { annual mean wind speed of } 4.80 \mathrm{~m} / \mathrm{s} \text { and power density of } 103.14 \mathrm{~W} / \mathrm{m}^{2} \text {. }\end{array}$ & {$[30]$} \\
\hline $\begin{array}{l}\text { Omu-Aran } \\
\text { Kwara State }\end{array}$ & $\begin{array}{l}\text { The highest average wind speed obtained at } 10 \mathrm{~m} \text { height was } 7925 \mathrm{~m} / \mathrm{s} \\
\text { with a minimum value of } 3675 \mathrm{~m} / \mathrm{s} .\end{array}$ & [33] \\
\hline South-south & $\begin{array}{l}\text { Other wind speed estimated to be } 3.21 \text { to } 4.19 \mathrm{~m} / \mathrm{s} \text { at } 10 \mathrm{~m} \text { height. } \\
\text { The mean power density and annual energy varied in different locations } \\
\text { as } 6.28 \leq \mathrm{APD} \leq 102.90 \mathrm{~W} / \mathrm{m}^{2} \text { and } 422 \leq \mathrm{AE} \leq 747 \mathrm{kWh} / \mathrm{m}^{2} \text { per year, } \\
\text { accordingly. The average wind speed depicted was } 2.1 \text { to } 3.0 \mathrm{~m} / \mathrm{s} \text { while } \\
\text { wind power density ranged from } 6.0 \text { to } 16.3 \mathrm{~W} / \mathrm{m}^{2} \text {. The average wind } \\
\text { speed for the coast region of south-south was measured as } 2.1 \text { to } 3.0 \mathrm{~m} / \mathrm{s} \\
\text { and the value of power density was } 6.0 \text { to } 16.3 \mathrm{~W} / \mathrm{m}^{2} \text { using the Weibull } \\
\text { distribution function. }\end{array}$ & {$[14,39,57,68]$} \\
\hline Akure & $\begin{array}{l}\text { The mean power density recorded was } 22.26 \mathrm{~W} / \mathrm{m}^{2} \text { and } 18.51 \mathrm{~W} / \mathrm{m}^{2} \text { for } \\
\text { both Rayleigh and Weibull, accordingly, while their corresponding } \\
\text { mean wind speed was } 2.70 \mathrm{~m} / \mathrm{s} \text { and } 2.71 \mathrm{~m} / \mathrm{s} \text {. }\end{array}$ & [37] \\
\hline North-central & $\begin{array}{l}\text { The resulting wind speed was found to be } 0.9 \text { to } 13.1 \mathrm{~m} / \mathrm{s} \text {, having a } \\
\text { mean absolute percentage error of } 8.9 \% \text {. Their power density fell in the } \\
\text { range } 16.57-76.40 \mathrm{~W} / \mathrm{m}^{2} \text { while annual average wind speed was } \\
2.75 \text { to } 4.57 \mathrm{~m} / \mathrm{s} \text {. }\end{array}$ & {$[41,42]$} \\
\hline Niger-Delta & $\begin{array}{l}\text { The annual energy output was } 4.07 \text { to } 145.6 \mathrm{MWH} \text {. It was asserted that } \\
\qquad 35 \mathrm{~kW} \text { wind energy turbine was recommended. }\end{array}$ & [43] \\
\hline Umudieke & The annual wind power estimated was $3101 \mathrm{KWh} / \mathrm{m}^{2}$ in this location. & {$[44]$} \\
\hline
\end{tabular}


Table 1. Cont.

\begin{tabular}{|c|c|c|}
\hline Site & Reported Data & Ref. \\
\hline $\begin{array}{l}\text { Abeokuta and } \\
\text { Ijebu-Ode }\end{array}$ & $\begin{array}{l}\text { The yearly mean wind speed for the two sites fell between } 2 \text { to } 5 \mathrm{~m} / \mathrm{s} \\
\text { while their power density was } 4.26 \text { to } 76.46 \mathrm{~W} / \mathrm{m}^{2} \text {. }\end{array}$ & [47] \\
\hline $\begin{array}{l}\text { Danjawa village, } \\
\text { Sokoto State }\end{array}$ & $\begin{array}{l}\text { The average wind speed was } 4.40 \text { to } 7.89 \mathrm{~m} / \mathrm{s} \text { and mean power density } \\
\text { resulted in } 7.65 \text { to } 92.90 \mathrm{~W} / \mathrm{m}^{2} .\end{array}$ & [56] \\
\hline $\begin{array}{l}\text { Warri, Calabar, } \\
\text { and Kastina }\end{array}$ & $\begin{array}{l}\text { Their average wind speed in the wet season was } 7.62,7.64 \text {, and } 7.61 \mathrm{~m} / \mathrm{s} \text {, } \\
\text { while their wind power densities were } 257.75,259.55 \text {, and } 257.11 \mathrm{~W} / \mathrm{m}^{2} \text {, } \\
\text { respectively. The dry seasonal average wind speed was } 9.17,9.20 \text {, } \\
\text { and } 9.17 \mathrm{~m} / \mathrm{s} \text {, and their corresponding power densities were } 449.73 \text {, } \\
454.10 \text {, and } 449.12 \mathrm{~W} / \mathrm{m}^{2} .\end{array}$ & [59] \\
\hline $\begin{array}{l}\text { Bauchi, Sokoto, } \\
\text { Abeokuta, Lokoja, } \\
\text { Port Harcourt } \\
\text { and Owerri }\end{array}$ & $\begin{array}{l}\text { Their average wind speed per year were as follow; } 4.37,4.33,2.76,4.52 \text {, } \\
3.27,3.25 \mathrm{~m} / \mathrm{s} \text {, respectively, while their corresponding power densities } \\
\text { were } 59.56,49.14,14.22,69.94,23.76 \text {, snd } 25.77 \mathrm{~W} / \mathrm{m}^{2} \text {. }\end{array}$ & [60] \\
\hline Makurdi & $\begin{array}{l}\text { The wind speed obtained was more than the } 4 \mathrm{~m} / \mathrm{s} \text { threshold for turbine } \\
\text { operation and its annual average power density was } 86.85 \mathrm{~W} / \mathrm{m}^{2} \text {. }\end{array}$ & [62] \\
\hline Kano & $\begin{array}{l}\text { Monthly average wind speeds of } 6.6 \text { to } 9.5 \mathrm{~m} / \mathrm{s} \text { and a montly power } \\
\text { density of } 3.6 \text { to } 12.5 \mathrm{MWh} / \mathrm{m}^{2}\end{array}$ & [63] \\
\hline South-east & $\begin{array}{l}\text { Annual average wind speeds for Onisha, Enugu and Owerri were 3.59, } \\
\text { 5.42, and } 3.36 \mathrm{~m} / \mathrm{s} \text { while their respected power densities were 28.34, } \\
99.98 \text {, and } 23.3 \mathrm{~W} / \mathrm{m}^{2}\end{array}$ & [64] \\
\hline $\begin{array}{l}\text { Port Harcourt, } \\
\text { River State }\end{array}$ & $\begin{array}{l}\text { The mean wind velocity obtained was } 17.75 \mathrm{~m} / \mathrm{s} \text {, with a power density } \\
\text { function of } 1370 \mathrm{~W} / \mathrm{m}^{2} \text { at a hub height of } 50 \mathrm{~m} .\end{array}$ & [65] \\
\hline $\begin{array}{l}\text { Koluama, } \\
\text { Bayelsa State }\end{array}$ & $\begin{array}{l}\text { The average wind speed recorded during dry season was } 4.05 \mathrm{~m} / \mathrm{s} \text { while } \\
\text { the rainy season was estimated to be } 4.32 \mathrm{~m} / \mathrm{s} \text {. The wind power density } \\
\text { fell within } 82 \text { to } 145 \mathrm{~W} / \mathrm{m}^{2}\end{array}$ & [66] \\
\hline
\end{tabular}

\section{Studies on Economic Analysis of Wind Energy Resources}

It is imperative to actualize the cost of producing various energy systems when referred to site resources available. The following studies show various cost analysis in different locations. The majority of costs were explored using levelized cost and present value cost. However, some studies base their analysis on specific turbines system or ratings that have been operated in other countries of the world. The economic estimation was done by adopting the levelized cost method. The results give energy production in $\mathrm{kWh}$ for all sites that fall between $\$ 0.090$ and $\$ 2.118$ in the southern part of Nigeria [26]. A similar approach was adopted for north-central, with values ranging between $₫ 4.02$ and $\$ 166.79$ per $\mathrm{kWh}[31]$. As for the south-west region, levelized cost with power capacity values at 0.6 to $2 \mathrm{MW}$ for various hub heights in different location were estimated to be in the range of 0.06997 and $0.11195 \$ /(\mathrm{kW} \$ \mathrm{~h})$ to 2.86611 and $4.58578 \$ /(\mathrm{kW} \$ \mathrm{~h})$, based on 1000 and $1600 \$ / \mathrm{kW}$ [32]. Based on two values of maintenance as well as an annual operation cost of $25 \%$ and $15 \%$ total initial cost, respectively, the feasibility of economic implication was deduced for the two wind energy power generation as $€ 0.025, € 0.026$, and $€ 0.015$, $€ 0.016$ per $\mathrm{kWh}$ [69]. The cost of producing wind energy in the south-west region was calculated to be in the range $0.02-5.03 € / \mathrm{kW}$, varying with the turbine model utilized [25]. The cost analysis done by Okeniyi using power law was $0.9909 € / \mathrm{kWh}$ at $10 \mathrm{~m}$ height and by extrapolation to a $110 \mathrm{~m}$ height resulted in a significant reduction of the cost [37]. Assessment of resources for hybrid wind and solar was simulated in a rural community in the south-eastern part of Nigeria, and it was concluded that it is more cost-effective compared to conventional fossil energy [70]. The standalone wind energy device for Maiduguri were investigated using levelized cost and life cycle assessment, the cost of producing wind was $\$ 0.17$ per KWh, which appears to be competitive with the grid connection system [71]. The cost analysis depicts Jos as the most cost effective site compared to Katsina, Enugu, and Kaduna with a COE amounting to $0.15 \$ / \mathrm{kWh}$, which is nearly 
similar to the global average value of $0.14 \$ / \mathrm{kWh}$ in households [50]. Effiom explored the economics of offshore project installation in Nigeria utilizing $500 \mathrm{MW}$ farm for the five stages involved. It was discovered that production and acquisition cover $55 \%$ of the project and operational expenditure and capital expenditure were $\$ 246,875 / \mathrm{kW} / \mathrm{yr}$ and $\$ 4,528,125 / \mathrm{kW}$, respectively [72]. The levelized cost was analysed using parameters of the Guangmang generator having a 2-kW rating for the wind turbine in Danjawa village. The outcome depicted an annual value of $1520.38 \mathrm{kWh}$ at a rate of N 326 per $\mathrm{kWh}$ [56]. The cost analysis in three cities, namely; Warri, Calabar, and Kaduna, were estimated to be 0.0774 , 0.0819 , and $0.0507 € / \mathrm{kWh}$ [59]. Modeling cost of a hybrid solar/wind system was $\$ 317,907$, which is more cost effective compared to a gasoline engine at a rate of $\$ 374,237$ [73]. The economic analysis of multiple renewable energy system was simulated using levelized cost. The value per $\mathrm{kWh}$ obtained was 0.0110 to $0.0095 \$$ for a household demand of $355 \mathrm{kWh}$ as a grid connected system [8]. Different kinds of wind turbine systems were explored to describe the most effective conversion technique using the adopted present value cost and levelized cost in the six regions of Nigeria [48]. The reseachers tried their best at estimating the cost implication using the available data. It must be emphasized that their analysis was not related to an existing wind energy device in Nigeria, which would have validated the costing. An accurate power factor estimation using recent techniques, as researchers are improving and modifying the existing methods, was a necessary ingredient for reliable values. Moreover, the effect of inflation rate, gross domestic product, interest rate, and the current electricity should be incorporated into various analysis. Therefore, the government should fund research and development in universities to provide a platform for a prototype wind device and formulate a new policy that will attract investors to renewable energy system. The studies were summarized in Table 2 .

Table 2. Summary of studies on economic analysis of wind energy

\begin{tabular}{|c|c|c|c|}
\hline Sites & Methods & Cost & Sources \\
\hline Southern part & Levelized cost & Between $\$ 0.090$ and $\$ 2.118$ per $\mathrm{kWh}$. & [26] \\
\hline North-central & Levelized cost & Between $₫ 4.02$ and $₫ 166.79$ per $\mathrm{kWh}$. & [31] \\
\hline South-west & $\begin{array}{l}\text { Levelized cost. } \\
\text { Power law }\end{array}$ & $\begin{array}{c}1000 \text { and } 1600 \$ / \mathrm{kW} .0 .02-5.03 € / \mathrm{kW} \text {. } \\
0.9909 € / \mathrm{kWh} \text {. }\end{array}$ & {$[32,37]$} \\
\hline Jos, Plateau State & $\begin{array}{l}\text { Present value cost } \\
\text { Cost of energy } \\
\text { (COE) }\end{array}$ & $\begin{array}{l}€ 0.025, € 0.026 \text {, and } € 0.015, € 0.016 \text { per } \mathrm{kWh} \text {. } \\
0.15 \$ / \mathrm{kWh}\end{array}$ & {$[50,69]$} \\
\hline Maiduguri & $\begin{array}{l}\text { Levelized cost and } \\
\text { life cycle } \\
\text { assessment }\end{array}$ & $\$ 0.17$ per kWh & [71] \\
\hline Nigeria & Levelized cost & $\begin{array}{l}\text { Operational expenditure and capital } \\
\text { expenditure were } \$ 246.875 / \mathrm{kW} / \mathrm{yr} \text { and } \\
\$ 4528.125 / \mathrm{kW} \text {, respectively. } \$ 317,907 \text {. }\end{array}$ & [72] \\
\hline Danjawa village & Levelized cost & $\begin{array}{c}\text { Annual value of } 1520.38 \mathrm{kWh} \text { at a rate of } \mathrm{N} \\
326 \text { per } \mathrm{kWh} \text {. }\end{array}$ & [56] \\
\hline $\begin{array}{l}\text { Warri, Calabar, } \\
\text { and Kaduna }\end{array}$ & Levelized cost & $0.0774,0.0819$, and $0.0507 € / \mathrm{kWh}$ & [59] \\
\hline
\end{tabular}

\section{Hybrid Analysis of Wind Energy System}

The combination of a conventional energy system with various renewable energies has been explored by many researchers for an optimum design, either as standalone or grid connected system. It paves way for one energy system to compensate for others that work in shortage as a hybrid system. These studies suggested the application of a hybrid system in a rural area, which includes wind energy resources and are appropriate for healthcare facilities [74-76]. The sizing of an optimal method to obtain an autonomous mini-grid system consists of wind, solar, a diesel-generator, and a battery storage system, which were simulated using the grasshopper optimization algorithm in combination with an energy management scheme. Five housing units that are off-grid were considered. The algorithm 
performs better compared to a previously applied method and the minimum cost obtained was $0.365 \$ / \mathrm{kWh}$ [77]. A hybrid system was assessed in terms of resources as well as cost effectiveness for the Sokoto State, Nigeria, in a community that is not connected to the grid system. The following designs were considered: wind/diesel, solar/diesel, wind/solar and standalone wind energy, diesel engine, and solar energy. The optimal energy was discovered to be wind energy standalone system based on levelized cost and life cycle assessment using the HOMER (Hybrid Optimization Model for Electrical Renewable) software [78]. Ayodele explored a hybrid system for a mini-grid system in Kwara State Ajasse Ipo. It was concluded that a hybrid system containing a battery/solar energy/ diesel generator was the most viable in terms of cost, which amounted to $0.667 \$ / \mathrm{kWh}$ [79]. This work evaluated the hybrid system in a rural community (Abadam, northern region), based on yearly interest rate as it impacted the economic viability of each composite systems. At a lower rate of interest less than $7 \%$, a hybrid system involves wind energy/solar energy/battery storage system, and shows as the most appropriate system, whereas wind energy/diesel engine system/battery storage system/solar energy was compatible with an interest rate of more than 7\% [80]. In a hybrid simulation embarked by the University of Ilorin, Kwara State, exploring a Power Quality and Energy Analyzer, a solar/diesel engine/ battery storage system combination was the most competitive in respect to resources and costing. The two wind energy systems compared to the hybrid results were inappropriate from an economic and technical point of view [81]. A hybrid system of solar and wind energy was studied for the rural areas of Nsukka in the south-eastern region of Nigeria, which was suitable for standalone system [82], and a similar one in the south-south region [14]. The wind and solar energy resources were estimated for hybrid application in the six regions of Nigeria, based on 500 remote household communities. It was discovered that the HOMER software reflected that Warri was the most cost effective, while Maidugri showed less [83]. Additionally, eight different hybrid configurations for wind/solar energy/battery storage system/biomass were captured for all the geo-political zones in Nigeria, and solar energy/biomass/battery storage system was the most effective for all the locations by applying multi-criterial analysis [47]. Likewise, Oluseyi laid emphasis on solar/wind energy hybridization in the north-central region by adopting the HOMER software. The analyses favored the hybrid of solar/ wind energy in Lokoja, Abuja, Makurdi, and Ilorin, whereas non-grid connection of wind energy provided optimal generation configuration for both Jos and Minna $[14,84,85]$. This research was based on hybrid wind/solar energy system, and is for mobile base station using HOMER software. A hybrid of solar/battery storage system/diesel engine was depicted as the best viable option $[8,86]$. The possibility of adopted solar and wind energy in combination with a battery storage system and a water pumping system based on daily demand were simulated in the central part of Nigeria. The outcome shows the viability of the system to produce the daily requirement, but the solar energy system was the best alternative in term of costing [55]. A new study suggested solar parks in combination with wind assisted parks for a hybrid system in Nigeria $[87,88]$. The life cycle assessment was done for a hybrid system that integrated wind energy resources and other renewable energy, which affirmed the lowest negative impacts to the environment [89]. Regarding a wind and solar hybrid system and a future demand in Nigeria, there might be a need to import more energy to meet up with the demand [90]. This research work described a hybrid nanogrid energy system for renewable energy which meets the energy demand of rural community [91]. The hybrid solar/wind was investigated for a household unit using HOMER in UNN (University of Nigeria Nsukka) [73]. Additionally, hybrid wind/solar was conceptualized along the coastal part of the south-south region [14]. The utilization of hybrid system containing hydro/wind/solar was studied for a coastal area named Patani using a genetic algorithm [92]. Similarly, a grid-connected hybrid system involved solar/wind/biogas was simulated using the HOMER software [93]. This research demonstrated the effectiveness of the Weibull distribution functions compared to the Rayleigh distribution, which was less effective [94]. Generally, the optimal design of hybrid energy system in the literatures enumerated above was conceptualized using the HOMER software. Other techniques used are the grasshopper optimization algorithm and the power quality energy analyzer. Moreover, the integration of a diesel engine with wind, solar, battery 
storage, and biomass was proven to be effective in terms of energy demand and cost effectiveness when compared with the current electricity price. The suitability of these hybrid systems for health care facilities in rural communities will significantly contribute to the improvement of the welfare of the host community. Additionally, the southern part, which was predominantly a low regime, should be explored for the hybrid system and others could be integrated into a grid system. The hybrid of a solar system in Nigeria context has been a success story for rural electrification agency (REA) and the World Bank, which funded the project in partnership with the federal government. The overall studies were depicted in Table 3.

Table 3. Summary of literatures on hybrid system.

\begin{tabular}{|c|c|c|c|}
\hline Site & Hybrid & Software & Ref. \\
\hline Rural area & Solar/wind/diesel & HOMER & [74-76] \\
\hline Yobe State & Solar/wind/battery/diesel & $\begin{array}{l}\text { Grasshopper optimization } \\
\text { algorithm and power } \\
\text { quality analyzer }\end{array}$ & [77] \\
\hline Sokoto State & Solar/wind/diesel & HOMER & [78] \\
\hline Ajase Ipo & Battery/solar/gasoline & HOMER & [79] \\
\hline Abadam, Nothern region & Wind/solar/battery & HOMER & [80] \\
\hline Ilorin, Kwara State & $\begin{array}{c}\text { Solar/diesel } \\
\text { engine/battery }\end{array}$ & Power quality analyzer & [81] \\
\hline Nsukka & $\begin{array}{l}\text { Solar/wind } \\
\text { Wind/solar }\end{array}$ & HOMER & {$[73,82,83]$} \\
\hline Nigeria, coastal area & $\begin{array}{c}\text { Solar/biomass/battery/ } \\
\text { solar parks }\end{array}$ & HOMER & {$[8,14,84-89]$} \\
\hline South-south & Wind/solar & HOMER & [93] \\
\hline
\end{tabular}

\section{Reanalysis of Reported Data}

The reported wind speed in Table 1 was extrapolated to 20, 40, 60, 80, 100, and $120 \mathrm{~m}$ height using the power law [30], as depicted in the Equation (1):

$$
V m 2=V m 1\left(\frac{H m 2}{H m 1}\right)^{\alpha}
$$

where $V m 2$ and $V m 1$ are wind speeds at reference height and $10 m$ height, respectively. $H m 2$ and $H m 1$ are the corresponding heights at the reference height and $10 \mathrm{~m} . \propto$ Represents the surface roughness as commonly used with the value of 0.143 . The graph of the extrapolated values was shown in Figure 1.

The Weibull function has been affirmed as the best fit for wind speed distributions and past studies have explored the technique of evaluating Weibull distribution parameters, which gave the most accurate results for wind energy production [95]. The two-way parameter Weibull probability density function was utilized for this study, as it has proven to be a useful tool by past studies on the assessment of wind energy resources.

The probability density function is;

$$
\begin{gathered}
F(v)=\left(\frac{k}{c}\right)\left(\frac{v}{c}\right)^{k-1} \exp \left[-\left(\frac{v}{c}\right)^{k}\right], \\
F(v)=1-\exp \left[-\left(\frac{v}{c}\right) k\right]
\end{gathered}
$$

where $V$ is the wind speed in meter per seconds; $k$ is the shape parameter with no unit; $C$ is the scale parameter in $\mathrm{ms}^{-1}$. Weibull parameters were obtained using the maximum likelihood method as it showed good performance [96,97]. The mean power densities in $\mathrm{W} / \mathrm{m}^{2}$ at $10,20,40,60,80,100$, 
and $120 \mathrm{~m}$ were also calculated using the probability density function, as depicted in the Equation (4). The results are shown in Table 4.

$$
P_{d}=\int_{0}^{\infty} 0.5 \rho v^{3} f(v) d v^{\prime}
$$

where $P_{d}$ is wind power $\left(\mathrm{W} / \mathrm{m}^{2}\right)$, and $\rho$ is the air density taken as $1.225 \mathrm{~kg} / \mathrm{m}^{3}$.

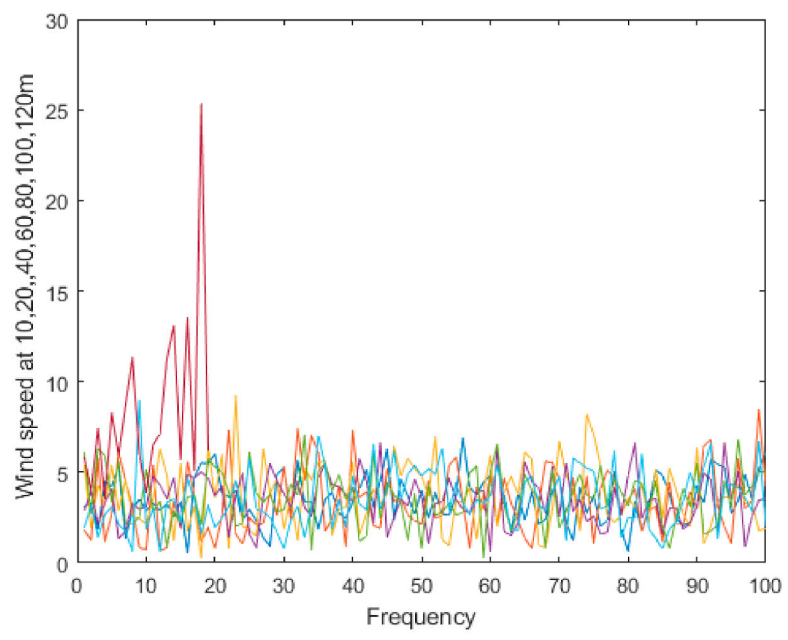

Figure 1. Graph of wind speed at 10, 20, 40, 60, 80, 100, and $120 \mathrm{~m}$.

Table 4. Weibull parameters and mean power densities at different heights.

\begin{tabular}{cccc}
\hline Height $(\mathbf{m})$ & Scale Parameter $(\mathbf{m} / \mathbf{s})$ & Shape Parameter $($ No Unit) & Mean Power Density $\left(\mathbf{W} / \mathbf{m}^{\mathbf{2}}\right)$ \\
\hline 10 & 3.93 & 2.88 & 38.68 \\
20 & 3.81 & 1.96 & 62.35 \\
40 & 4.20 & 2.17 & 57.99 \\
60 & 3.92 & 2.79 & 39.41 \\
80 & 4.07 & 2.58 & 47.85 \\
100 & 3.95 & 2.28 & 52.90 \\
120 & 9.48 & 2.88 & 1257.2 \\
\hline
\end{tabular}

\section{Research Recommendation and Suggestion}

The land base system has been extensively researched in term of resource assessment and its potentiality. In order to show higher precision, reliability of the measured values, the data sets need to be validated by other sources of data acquisition. As we are witnessing in the United States of America, the influence of government policy on science or more specific renewable energy cannot be underrated. The stakeholders in wind energy development in Nigeria should emphasize the importance of deploring wind energy systems in terms of economic benefits as well as reducing the emission rate to the government. The on-site assessment for the locations should be taken into consideration, and topographic characteristics of the site need to be incorporated as well in the analysis. However, there exists poor funding of research and development, and an inability to align our education system with industries that will in turn improve the productivity of the graduate. Therefore, the appropriate utilization of the Tertiary Education Trust Fund (TETFund) could help in achieving a milestone in the renewable energy development in Nigeria. The lack of literature in coastal parts of Nigeria hinders the development of offshore projects. More studies should be conducted in the nearshore and offshore environments. As we witness the development of the solar energy system and its hybrid, special attention should be given to wind/solar/battery storage system/ diesel engine hybridization. The effect of deforestation, carbon IV oxide emission should be incorporated when researching the hybrid system. There is a need to design a best FIT (Feed-in Tariff) scheme in Nigeria for all available 
renewable energy systems, which must prioritize attracting investors towards renewable energy projects, since it was established in the developed part of the world, which institutionalized the FIT regime advanced renewable energy deployment. More research should be conducted on what types of efficiency enhancement models could be employed for various turbine configurations. The federal government should encourage researchers to do more studies on renewable energy system, especially wind energy, by funding research and developments as opined in the renewable energy policy.

\section{Conclusions}

The primary objectives of this study have been achieved by reviewing the past and present studies on wind energy in Nigeria. The studied cases were thoroughly investigated based on an assessment of wind energy resources, the economy of wind energy resources, hybrid analysis of wind energy system, as well as recommendations, which were drawn from the studies. The southern part of Nigeria consists of a low wind speed regime apart from the coastal section that shows a viable energy system, which can be integrated by a grid or used to serve a nearby island. However, the utilization of hybrid system in the south will be more appropriate and can be employed in a small scale such as in a pumping system. The northern part depicts prevailing wind that could be employed in a large-scale wind turbine system such as the one in the Kastina State of 10 MW capacity. At the end of each section, the research gap was enumerated. Likewise, each section was discussed based on the literatures available and what could be done to improve the research. Then, the reported wind speed was analyzed to reflect various power densities at different heights. Finally, recommendations were suggested for both the governments and the researchers. It is my belief that with enormous potential we have, wind energy could be create economic benefits and serve as the solution to an erratic power supply.

Author Contributions: Conceptualization, W.O.I. and M.Z.I.; methodology, W.O.I.; software, W.O.I.; validation, A.A.; writing-review and editing, M.Z.I., A.A.; supervision, M.Z.I. All authors have read and agreed to the published version of the manuscript.

Funding: This research received no external funding.

Acknowledgments: I am grateful to the Almighty Allah for His guidance. My greeting extends to the Faculty of Ocean Engineering, Technology and Informatics Universiti Malaysia Terengganu (UMT). I am thankful to the UMT authority for granting me the Postgraduate Student Incentive Scheme (PSIS). A special thanks goes out to friends and family for their support.

Conflicts of Interest: The authors of this paper declare that there is no conflict of interest.

\section{References}

1. Eme, L.C.; Ulasi, J.A.; Tunde, A.I.A.; Odunze, A.C. Hydrokinetic turbines for power generation in Nigerian river basins. Water Pract. Technol. 2019, 14, 71-80. [CrossRef]

2. Mas'ud, A.A.; Vernyuy Wirba, A.; Muhammad-Sukki, F.; Mas'ud, I.A.; Munir, A.B.; Md Yunus, N. An assessment of renewable energy readiness in Africa: Case study of Nigeria and Cameroon. Renew. Sustain. Energy Rev. 2015, 51, 775-784. [CrossRef]

3. Aliyu, A.S.; Dada, J.O.; Adam, I.K. Current status and future prospects of renewable energy in Nigeria. Renew. Sustain. Energy Rev. 2015, 48, 336-346. [CrossRef]

4. Global Wind Energy Council. Global Wind Report 2018; Global Wind Energy Council: Brussels, Belgium, 2019; Available online: https:/www.google.com/search?client=firefox-b-d\&q=global+winnd+energy+report (accessed on 19 November 2019).

5. Olaofe, Z.O. Review of energy systems deployment and development of offshore wind energy resource map at the coastal regions of Africa. Energy 2018, 161, 1096-1114. [CrossRef]

6. Pacheco, A.; Gorbeña, E.; Sequeira, C.; Jerez, S. An evaluation of offshore wind power production by floatable systems: A case study from SW Portugal. Energy 2017, 131, 239-250. [CrossRef]

7. Zuo, H.; Bi, K.; Hao, H. A state-of-the-art review on the vibration mitigation of wind turbines. Renew. Sustain. Energy Rev. 2020, 121, 109710. [CrossRef]

8. Tijjani, A.; Wei, C. Optimal sizing and techno-economic analysis of grid-connected nanogrid for tropical climates of the Savannah. Sustain. Cities Soc. 2020, 52, 101824. [CrossRef] 
9. Bamisile, O.; Huang, Q.; Xu, X.; Hu, W.; Liu, W.; Liu, Z.; Chen, Z. An approach for sustainable energy planning towards $100 \%$ electrification of Nigeria by 2030. Energy 2020, 197. [CrossRef]

10. Ajayi, O.O. Assessment of utilization of wind energy resources in Nigeria. Energy Policy 2009. [CrossRef]

11. Somorin, T.O.; Adesola, S.; Kolawole, A. State-level assessment of the waste-to-energy potential (via incineration) of municipal solid wastes in Nigeria. J. Clean. Prod. 2017. [CrossRef]

12. Ohunakin, S.O.; Ojolo, S.J.; Ogunsina, S.B.; Dinrifo, R.R. Analysis of cost estimation and wind energy evaluation using wind energy conversion systems (WECS) for electricity generation in six selected high altitude locations in Nigeria. Energy Policy 2012, 48, 594-600. [CrossRef]

13. Ohunakin, O.S. Wind resource evaluation in six selected high altitude locations in Nigeria. Renew. Energy 2011. [CrossRef]

14. Diemuodeke, E.O.; Addo, A.; Oko, C.O.C.; Mulugetta, Y.; Ojapah, M.M. Optimal mapping of hybrid renewable energy systems for locations using multi-criteria decision-making algorithm. Renew. Energy 2019. [CrossRef]

15. Mentis, D.; Welsch, M.; Fuso Nerini, F.; Broad, O.; Howells, M.; Bazilian, M.; Rogner, H. A GIS-based approach for electrification planning-A case study on Nigeria. Energy Sustain. Dev. 2015. [CrossRef]

16. Esan, A.B.; Agbetuyi, A.F.; Oghorada, O.; Ogbeide, K.; Awelewa, A.A.; Afolabi, A.E. Reliability assessments of an islanded hybrid PV-diesel-battery system for a typical rural community in Nigeria. Heliyon 2019, 5, e01632. [CrossRef]

17. Aririguzo, J.C.; Ekwe, E.B. Weibull distribution analysis of wind energy prospect for Umudike, Nigeria for power generation. Robot. Comput. Integr. Manuf. 2019. [CrossRef]

18. Adaramola, M.S.; Oyewola, O.M. On wind speed pattern and energy potential in Nigeria mmm. Energy Policy 2011. [CrossRef]

19. Ojosu, J.O.; Salawu, R.I. A survey of wind energy potential in Nigeria. Sol. Wind Technol. 1990. [CrossRef]

20. Adekoya, L.O.; Adewale, A.A. Wind energy potential of Nigeria. Renew. Energy 1992. [CrossRef]

21. Anyanwu, E.E.; Iwuagwu, C.J. Wind characteristics and energy potentials for Owerri, Nigeria. Renew. Energy 1995. [CrossRef]

22. Ngala, G.M.; Alkali, B.; Aji, M.A. Viability of wind energy as a power generation source in Maiduguri, Borno state, Nigeria. Renew. Energy 2007. [CrossRef]

23. Fadare, D.A.; State, O. A Statistical Analysis of Wind Energy Potential in Ibadan, Nigeria, Based on Weibull Distribution Function. Pac. J. Sci. Technol. 2008, 9, 110-119.

24. Odo, F.C.; Offiah, S.U.; Ugwuoke, P.E. Weibull distribution-based model for prediction of wind potential in Enugu, Nigeria. Adv. Appl. Sci. Res. 2012, 3, 1202-1208.

25. Ajayi, O.O.; Fagbenle, R.O.; Katende, J.; Ndambuki, J.M.; Omole, D.O.; Badejo, A.A. Wind energy study and energy cost of wind electricity generation in Nigeria: Past and recent results and a case study for South West Nigeria. Energies 2014, 7, 8508. [CrossRef]

26. Paul, S.S.; Oyedepo, S.O.; Adaramola, M.S. Economic assessment of water pumping systems using wind energy conversion systems in the southern part of Nigeria. Energy Explor. Exploit. 2012, 30, 1-17. [CrossRef]

27. Ajayi, O.O.; Fagbenle, R.O.; Katende, J.; Okeniyi, J.O. Availability of wind energy resource potential for power generation at Jos, Nigeria. Front. Energy 2011. [CrossRef]

28. Fagbenle, R.O.; Katende, J.; Ajayi, O.O.; Okeniyi, J.O. Assessment of wind energy potential of two sites in North-East, Nigeria. Renew. Energy 2011, 36, 1277-1283. [CrossRef]

29. Okundamiya, M.S.; Nzeako, A.N.; Okundamiya, M.S.; Nzeako, A.N. Model for optimal sizing of a wind energy conversion system for Green-Mobile applications. Int. J. Green Energy 2013, 5075. [CrossRef]

30. Ohunakin, O.S. Wind resources in North-East geopolitical zone, Nigeria: An assessment of the monthly and seasonal characteristics. Renew. Sustain. Energy Rev. 2011, 15, 1977-1987. [CrossRef]

31. Adaramola, M.S.; Paul, S.S.; Oyedepo, S.O. Assessment of electricity generation and energy cost of wind energy conversion systems in north-central Nigeria. Energy Convers. Manag. 2011, 52, 3363-3368. [CrossRef]

32. Adaramola, M.S.; Oyewola, O.M.; Ohunakin, O.S.; Dinrifo, R.R. Techno-economic evaluation of wind energy in southwest Nigeria. Front. Energy 2012. [CrossRef]

33. Ikpotokin, I.; Osueke, C.O.; Olawale, O. Wind energy systems for Omu Aran, Kwara State, Nigeria. J. Phys. Conf. Ser. 2019. [CrossRef]

34. Adeniji, A.E.; Olusola, O.I.; Njah, A.N. Comparative study of chaotic features in hourly wind speed using recurrence quantification analysis. AIP Adv. 2018, 025102. [CrossRef] 
35. Matthew, O.J.; Ohunakin, O.S. Simulating the effects of climate change and afforestation on wind power potential in Nigeria. Sustain. Energy Technol. Assess. 2017, 22, 41-54. [CrossRef]

36. Ayodele, T.R.; Ogunjuyigbe, A.S.O.; Odigie, O.; Jimoh, A.A. On the most suitable sites for wind farm development in Nigeria. Data Br. 2018. [CrossRef]

37. Okeniyi, J.O.; Moses, I.F.; Okeniyi, E.T. Wind characteristics and energy potential assessment in Akure, South West Nigeria: Econometrics and policy implications. Int. J. Ambient Energy 2015, 36, 282-300. [CrossRef]

38. Salisu, S.; Wazir, M.; Olatomiwa, L. Assessment of technical and economic feasibility for a hybrid PV-wind-diesel-battery energy system in a remote community of north central Nigeria. Alex. Eng. J. 2019, 58, 1103-1118. [CrossRef]

39. Abam, F.I.; Ohunakin, O.S. Economics of wind energy utilisation for water pumping and $\mathrm{CO}_{2}$ mitigation potential in Niger. Int. J. Ambient Energy 2017, 0750. [CrossRef]

40. Ukoba, M.O.; Diemuodeke, O.E.; Alghassab, M.; Njoku, H.I.; Imran, M.; Khan, Z.A. Composite multi-criteria decision analysis for optimization of hybrid renewable energy systems for geopolitical zones in Nigeria. Mech. Eng. Des. 2020, 5732, 1-27.

41. Fadare, D.A. The application of artificial neural networks to mapping of wind speed profile for energy application in Nigeria. Appl. Energy 2010. [CrossRef]

42. Ohunakin, O.S. Assessment of wind energy resources for electricity generation using WECS in North-Central region, Nigeria. Renew. Sustain. Energy Rev. 2011, 15, 1968-1976. [CrossRef]

43. Adaramola, M.S.; Oyewola, O.M.; Ohunakin, O.S.; Akinnawonu, O.O. Performance evaluation of wind turbines for energy generation in Niger Delta, Nigeria. Sustain. Energy Technol. Assess. 2014. [CrossRef]

44. Okokpujie, I.P.; Okonkwo, U.C.; Bolu, C.A.; Ohunakin, O.S.; Agboola, M.G.; Atayero, A.A. Heliyon Implementation of multi-criteria decision method for selection of suitable material for development of horizontal wind turbine blade for sustainable energy generation. Heliyon 2020, 6, e03142. [CrossRef] [PubMed]

45. Ayodele, T.R.; Ogunjuyigbe, A.S.O.; Amusan, T.O. Wind power utilization assessment and economic analysis of wind turbines across fifteen locations in the six geographical zones of Nigeria. J. Clean. Prod. 2016. [CrossRef]

46. Ayodele, T.R.; Ogunjuyigbe, A.S.O.; Amusan, T.O. Techno-economic analysis of utilizing wind energy for water pumping in some selected communities of Oyo State, Nigeria. Renew. Sustain. Energy Rev. 2018, 91, 335-343. [CrossRef]

47. Amoo, O.M. Evaluation of the wind energy potential of two south west sites in Nigeria. Front. Energy 2012, 6, 237-246. [CrossRef]

48. Ohunakin, O.S.; Oyewola, O.M.; Adaramola, M.S. Economic analysis of wind energy conversion systems using levelized cost of electricity and present value cost methods in Nigeria. Int. J. Energy Environ. Eng. 2013. [CrossRef]

49. Emetere, M.E.; Akinyemi, M.L. Climate Variability and Renewable Energy Planning. In Proceedings of the International Conference on Energy and Sustainable Environment, Covenant University, Ogun, Nigeria, 18-20 June 2019. [CrossRef]

50. Diyoke, C. Comparative thermo-economic and advanced exergy performance assessment of wind energy for distributed generation in four sites in Nigeria. Int. J. Renew. Energy Dev. 2020, 9, 339-351. [CrossRef]

51. Adaramola, M.S.; Oyewola, O.M. Evaluating the performance of wind turbines in selected locations in Oyo state, Nigeria. Renew. Energy 2011. [CrossRef]

52. Ohunakin, O.S.; Adaramola, M.S.; Oyewola, O.M.; Fagbenle, R.O. Generation of a typical meteorological year for north-east, Nigeria. Appl. Energy 2013. [CrossRef]

53. Oyekola, P.; Mohamed, A.; Pumwa, J. Renewable energy: Dynamic modelling of a wind turbine. Int. J. Innov. Technol. Explor. Eng. 2019, 875-880. [CrossRef]

54. Cloutier, M.; Rowley, P. The feasibility of renewable energy sources for pumping clean water in sub-saharan Africa: A case study for Central Nigeria. Renew. Energy 2011. [CrossRef]

55. Sivla, W.T.; Ogunjobi, O.; Tesema, F. Thermospheric winds over Abuja during solar minimum period. Adv. Sp. Res. 2020, 65, 1424-1431. [CrossRef]

56. Argungu, G.M.; Moreh, A.U.; Abdullahi, S.; Hamza, B.; Aliyu, S.; Dabai, K.A.; Maiyama, B.A. Performance evaluation and cost of energy from $2.0 \mathrm{~kW}$ (Guangmang) wind turbine at danjawa renewable energy model village, Sokoto, Nigeria. IOSR J. Appl. Phys. 2016, 8, 28-34. [CrossRef] 
57. Dike, V.N.; Chineke, T.C.; Nwofor, O.; Okoro, U.; Dike, V.N.; Chineke, C.T.; Nwofor, O.K.; Okoro, U.K. Number 1. 2011, Volume 12. Available online: http://www.akamaiuniversity.us/PJST.htm (accessed on 28 September 2020).

58. Nze-Esiaga, N.; Okogbue, E.C. Assessment of Wind Energy Potential as a Power Generation Source in Five Locations of South Western Nigeria. J. Power Energy Eng. 2014, 02, 1-13. [CrossRef]

59. Okeniyi, J.O.; Ohunakin, O.S.; Okeniyi, E.T. Assessments of wind-energy potential in selected sites from three geopolitical zones in Nigeria: Implications for renewable/sustainable rural electrification. Sci. World J. 2015. [CrossRef]

60. Okoye, A.E.; Nwaji, G.N.; Ofong, I.; Anyanwu, E.E. Investigation of wind energy resource potential in six nigerian locations for power generation. IEEE-SEM 2020, 8, 27-40.

61. Ogolo, E.; Olusola, O.; Ogolo, E.O.; Apata, J.O.; Ojo, O.S. Harnessing wind energy potential for power generation in Nigeria. Eur. J. Adv. Eng. Technol. 2020, 7, 21-31.

62. Audu, M.O.; Terwase, A.S.; Isikwue, B.C. Investigation of wind speed characteristics and its energy potential in Makurdi, north central, Nigeria. SN Appl. Sci. 2019, 1, 1-6. [CrossRef]

63. Ajayi, O.O.; Fagbenle, R.O.; Katende, J.; Aasa, S.A.; Okeniyi, J.O. Wind profile characteristics and turbine performance analysis in Kano, north-western Nigeria. Int. J. Energy Environ. Eng. 2013. [CrossRef]

64. Oyedepo, S.O.; Adaramola, M.S.; Paul, S.S. Analysis of wind speed data and wind energy potential in three selected locations in South-East Nigeria. Int. J. Energy Environ. Eng. 2012. [CrossRef]

65. Izelu, C.O.; Agberegha, O.L.; Oguntuberu, O.B. Wind resource assessment for wind energy utilization in port harcourt, river state, nigeria, based on weibull probability distribution function. Int. J. Renew. Energy Res. 2013, 3, 180-185. [CrossRef]

66. Akinsanola, A.A.; Ogunjobi, K.O.; Abolude, A.T.; Sarris, S.C.; Ladipo, K.O. Assessment of wind energy potential for small communities in South-South Nigeria: Case study of Koluama, Bayelsa State. J. Fundam. Renew. Energy Appl. 2017, 07. [CrossRef]

67. Odo, F.C.; Akubue, G.U. Comparative assessment of three models for estimating weibull parameters for wind energy applications in a Nigerian Location. Int. J. Energy Sci. 2012, 2, 22-25.

68. Dike, V.N.; Sc, M.; Chineke, C.T.; Ph, D.; Nwofor, O.K.; Ph, D.; Okoro, U.K.; Sc, M. Estimating wind energy potential in some coastal cities of the Niger-Delta Region of Nigeria. Pac. J. Sci. Technol. 2011, 12, 598-604.

69. Ohunakin, O.S.; Akinnawonu, O.O. Assessment of wind energy potential and the economics of wind power generation in Jos, Plateau State, Nigeria. Energy Sustain. Dev. 2012, 16, 78-83. [CrossRef]

70. Ajayi, O.O.; Ohijeagbon, O.D. Feasibility and techno-economic assessment of stand-alone and hybrid RE for rural electrification in selected sites of south eastern Nigeria. Int. J. Ambient Energy 2017, 38, 55-68. [CrossRef]

71. Ajayi, O.O.; Ohijeagbon, O.D.; Mercy, O.; Ameh, A. Potential and econometrics analysis of standalone RE facility for rural community utilization and embedded generation in North-East, Nigeria. Sustain. Cities Soc. 2016, 21, 66-77. [CrossRef]

72. Effiom, S.O.; Nwankwojike, B.N.; Abam, F.I. Economic cost evaluation on the viability of offshore wind turbine farms in Nigeria. Energy Rep. 2016. [CrossRef]

73. Ani, V.A. Optimal energy system for single household in Nigeria. Int. J. Energy Optim. Eng. 2013, 2, $16-41$. [CrossRef]

74. Olatomiwa, L.; Mekhilef, S.; Ohunakin, O.S. Hybrid renewable power supply for rural health clinics (RHC) in six geo-political zones of Nigeria. Sustain. Energy Technol. Assess. 2016. [CrossRef]

75. Olatomiwa, L.; Mekhilef, S.; Huda, A.S.N.; Ohunakin, O.S. Economic evaluation of hybrid energy systems for rural electrification in six geo-political zones of Nigeria. Renew. Energy 2015. [CrossRef]

76. Olatomiwa, L.; Blanchard, R.; Mekhilef, S.; Akinyele, D. Hybrid renewable energy supply for rural healthcare facilities: An approach to quality healthcare delivery. Sustain. Energy Technol. Assess. 2018. [CrossRef]

77. Babatunde, O.M.; Adedoja, O.S.; Babatunde, D.E.; Denwigwe, I.H. Off-grid hybrid renewable energy system for rural healthcare centers: A case study in Nigeria. Energy Sci. Eng. 2019, 7, 676-693. [CrossRef]

78. Bukar, A.L.; Tan, C.W.; Lau, K.Y. Optimal sizing of an autonomous photovoltaic/wind/battery/diesel generator microgrid using grasshopper optimization algorithm. Sol. Energy 2019. [CrossRef]

79. Ohijeagbon, O.D.; Ajayi, O.O. Potential and economic viability of standalone hybrid systems for a rural community of Sokoto, North-west Nigeria. Front. Energy 2014. [CrossRef] 
80. Ayodele, E.; Misra, S.; Damasevicius, R.; Maskeliunas, R. Hybrid microgrid for microfinance institutions in rural areas-A field demonstration in West Africa. Sustain. Energy Technol. Assess. 2019, 35, 89-97. [CrossRef]

81. Babatunde, O.M.; Babatunde, D.E.; Denwigwe, I.H.; Adedoja, T.B.; Adedoja, O.S.; Mnsesmieee, E.T.E.O. Analysis of an optimal hybrid power system for an off-grid community in Nigeria. Int. J. Energy Sect. Manag. 2019, 14, 335-357. [CrossRef]

82. Ariyo, B.O.; Akorede, M.F.; Omeiza, I.O.A.; Amuda, S.A.Y.; Oladeji, S.A. Optimisation analysis of a stand-alone hybrid energy system for the senate building, university of Ilorin, Nigeria. J. Build. Eng. 2018, 19, 285-294. [CrossRef]

83. Odeh, C.I. Use of hybrid solar-wind energy generation for remote area electrification in South-Eastern Nigeria. J. Energy S. Afr. 2014, 25, 61-69.

84. Oyedepo, S.O.; Uwoghiren, T.; Babalola, P.O.; Nwanya, S.C.; Kilanko, O.; Leramo, R.O.; Aworinde, A.K.; Adekeye, T.; Oyebanji, J.A.; Abidakun, O.A. Assessment of decentralized electricity production from hybrid renewable energy sources for sustainable energy development in Nigeria. Open Eng. 2019, 9, 72-89. [CrossRef]

85. Ajayi, O.D.; Waheed, O.O.; Adekojo, M.; Salawu, E.Y. Design of Optimal Hybrid Renewable Energy System for Sustainable Power Supply to Isolated-grid Communities in North. Procedia Manuf. 2019, 35, 278-284. [CrossRef]

86. Diemuodeke, E.O.; Hamilton, S.; Addo, A. Multi-criteria assessment of hybrid renewable energy systems for Nigeria's coastline communities. Energy. Sustain. Soc. 2016. [CrossRef]

87. Olatomiwa, L.; Mekhilef, S.; Huda, A.S.N.; Sanusi, K. Techno-economic analysis of hybrid PV-diesel-battery and PV-wind-diesel-battery power systems for mobile BTS: The way forward for rural development. Energy Sci. Eng. 2015. [CrossRef]

88. Ikejemba, E.C.X.; Schuur, P.C. Designing a nation-wide network of solar and wind-assisted parks for Nigeria and for Ghana. Int. J. Energy Environ. Eng. 2016. [CrossRef]

89. Ikejemba, E.C.X.; Schuur, P. Locating solar and wind parks in South-Eastern Nigeria for maximum population coverage: A multi-step approach. Renew. Energy 2016. [CrossRef]

90. Jumare, I.A.; Bhandari, R.; Zerga, A. Environmental life cycle assessment of grid-integrated hybrid renewable energy systems in Northern Nigeria. Sustainability 2019, 11, 5889. [CrossRef]

91. Deng, Y.Y.; Haigh, M.; Pouwels, W.; Ramaekers, L.; Brandsma, R.; Schimschar, S.; Grözinger, J.; de Jager, D. Quantifying a realistic, worldwide wind and solar electricity supply. Glob. Environ. Chang. 2015. [CrossRef]

92. Akinyele, D. Techno-economic design and performance analysis of nanogrid systems for households in energy-poor villages. Sustain. Cities Soc. 2017, 34, 335-357. [CrossRef]

93. Nyeche, E.N.; Diemuodeke, E.O. Modelling and optimisation of a hybrid PV-wind turbine-pumped hydro storage energy system for mini-grid application in coastline communities. J. Clean. Prod. 2020, 250, 119578. [CrossRef]

94. Jumare, I.A.; Bhandari, R.; Zerga, A. Assessment of a decentralized grid-connected photovoltaic (PV)/wind/biogas hybrid power system in northern Nigeria. Energy. Sustain. Soc. 2020, 10, 1-25. [CrossRef]

95. Ahmed, A.; Bello, A.A.; Habou, D. An evaluation of wind energy potential in the Northern and Southern regions of Nigeria on the basis of Weibull and Rayleigh models. Am. J. Energy Eng. 2013, 1, 37-42. [CrossRef]

96. Costa Rocha, P.A.; de Sousa, R.C.; de Andrade, C.F.; da Silva, M.E.V. Comparison of seven numerical methods for determining Weibull parameters for wind energy generation in the northeast region of Brazil. Appl. Energy 2012, 89, 395-400. [CrossRef]

97. Wang, J.; Huang, X.; Li, Q.; Ma, X. Comparison of seven methods for determining the optimal statistical distribution parameters: A case study of wind energy assessment in the large-scale wind farms of China. Energy 2018, 164, 432-448. [CrossRef]

Publisher's Note: MDPI stays neutral with regard to jurisdictional claims in published maps and institutional affiliations. 